Research Paper

\title{
Application of decolourized and partially purified polygalacturonase and $\alpha$-amylase in apple juice clarification
}

\author{
Tapati Bhanja Dey ${ }^{1,2}$, Rintu Banerjee ${ }^{1}$ \\ ${ }^{1}$ Microbial Biotechnology and Downstream Processing Lab, \\ Agricultural and Food Engineering Department, Indian Institute of Technology, Kharagpur, India. \\ ${ }^{2}$ Lignocellulose Biotechnology Laboratory, Department of Microbiology, \\ University of Delhi South Campus, Benito Juarez Road, New Delhi, India.
}

Submitted: October 12, 2012; Approved: April 4, 2013.

\begin{abstract}
Polygalacturonase and $\alpha$-amylase play vital role in fruit juice industry. In the present study, polygalacturonase was produced by Aspergillus awamori Nakazawa MTCC 6652 utilizing apple pomace and mosambi orange (Citrus sinensis var mosambi) peels as solid substrate whereas, $\alpha$-amylase was produced from A. oryzae (IFO-30103) using wheat bran by solid state fermentation (SSF) process. These carbohydrases were decolourized and purified 8.6-fold, 34.8 -fold and 3.5 -fold, respectively by activated charcoal powder in a single step with $65.1 \%, 69.8 \%$ and $60 \%$ recoveries, respectively. Apple juice was clarified by these decolourized and partially purified enzymes. In presence of $1 \%$ polygalacturonase from mosambi peels $(9.87 \mathrm{U} / \mathrm{mL})$ and $0.4 \% \alpha$-amylase $(899 \mathrm{U} / \mathrm{mL})$, maximum clarity $\left(\% \mathrm{~T}_{660 \mathrm{~nm}}=97.0 \%\right)$ of juice was attained after $2 \mathrm{~h}$ of incubation at $50{ }^{\circ} \mathrm{C}$ in presence of $10 \mathrm{mM} \mathrm{CaCl}_{2}$. Total phenolic content of juice was reduced by $19.8 \%$ after clarification, yet with slightly higher \%DPPH radical scavenging property.
\end{abstract}

Key words: polygalacturonase, $\alpha$-amylase, activated charcoal, decolourization, apple juice clarification.

\section{Introduction}

Clarified apple juice is one of the most consumed fruit juices in the world next only to orange juice (Ceci and Lozano, 1998; Kahle et al., 2005). Raw apple juice obtained after pressing apples is turbid, brown in colour, very viscous and tends to settle during storage, so it must be clarified prior to its commercialization. Polysaccharides (pectin, cellulose, hemicellulose and starch), proteins, tannins, metals and microorganisms are mainly responsible for the apple juice turbidity. Conventional clarification processes aim to eliminate the insoluble solids and destroy pectic substances by degrading pectin and starch with specific enzymes, flocculating cloudiness with clarifying agents (bentonite, gelatine and/or silicasol) (Grampp, 1977) and filtering through plate and frame or vacuum Oliver-type filters. Pectin is the main substance responsible for cloudiness of apple juice. The process of depectinisation involves the use of commercial enzymes, generally a blend of pectinases (e.g., pectinase, polygalacturonase, pectinlyase) to degrade pectic substances. Another potential contributor to the haziness of juice is starch. In presence of starch, the following problems may occur: (i) slow filtration, (ii) membrane fouling, (iii) gelling after concentration and (iv) post concentration haze (Carrin et al., 2004). Both depectinisation and destarching are essential for most of the juice clarification process. Starch can be degraded by amylase together with the pectinases during depectinization of the juice. Amylase eliminates the possible action of starch molecules agglomerating with proteins, pectins and thus eliminates haze formation.

A common substrate for $\alpha$-amylase production by solid state fermentation (SSF) is wheat bran, whereas for pectinases (polygalacturonase, pectin methylesterase and pectinlyase) the substrate is pectin containing fruit peel. Enzyme extracted from these substrates contains various

Send correspondence to T.B. Dey. Lignocellulose Biotechnology Laboratory, Department of Microbiology, University of Delhi South Campus, Benito Juarez Road, 110021 New Delhi, India. E-mail: tapati_bhanja@yahoo.co.in, tapati.bhanja@gmail.com. 
impurities including a significant amount of melanine-like colouring matter, which can interfere in the juice clarification process if the enzymes are used in crude form. Generally enzymes are purified from this colour extract by various purification steps. The purification of the targeted biomolecules should be such that the selection of number of steps should be minimum and cost-effective, as the yield and the steps of operation are inversely proportional to each other. In the present study, for the commercial application of the $\alpha$-amylase and polygalacturonase in apple juice clarification, those enzymes were purified partially by activated charcoal in a single step.

$\alpha$-Amylases are calcium containing enzymes, binding at least one calcium ion per monomeric unit. The calcium ions impart resistance to $\mathrm{pH}$, temperature, proteolysis and denaturation by urea and heat. Thermostability of $\alpha$-amylase is increased by the calcium ion. Recently, many food industries have proposed the use of apple juices fortified with calcium as healthy and non-fat alternative, especially for children (Ceci and Lozano, 2002). Therefore, apple juice has been clarified in presence of calcium chloride.

\section{Materials and Methods}

\section{Organism, inoculum and chemicals}

Fungal strain $A$. oryzae (IFO-30103) donated by NIIST-Trivandrum, India and locally isolated $A$. awamori nakazawa were used for the present study. They were cultivated and maintained in potato dextrose agar (PDA). Spore suspension was prepared having a spore count of $1 \times 10^{6}$ spores $/ \mathrm{mL}$. For the production of $\alpha$-amylase, locally available wheat bran was used as a substrate which was screened to particle size 2-3 $\mathrm{mm}$. Apple pomace and mosambi (Citrus sinensis var mosambi) peel procured from local market were used for the polygalacturonase production. All chemicals and solvents used were of analytical grade.

\section{Fermentation conditions}

\section{Polygalacturonase production}

Apple pomace and mosambi peels were dried in a hot air oven at $80^{\circ} \mathrm{C}$ for $24 \mathrm{~h}$ and ground in mixer grinder. SSF was carried out in $250 \mathrm{~mL}$ Erlenmeyer flask taking $5 \mathrm{~g}$ of ground substrate. Czapek-dox medium $\left[\mathrm{NaNO}_{3}(2.5 \mathrm{~g} / \mathrm{L})\right.$, $\mathrm{KH}_{2} \mathrm{PO}_{4}(1 \mathrm{~g} / \mathrm{L}), \mathrm{KCl}(0.5 \mathrm{~g} / \mathrm{L})$ and $\left.\mathrm{MgSO}_{4} .2 \mathrm{H}_{2} \mathrm{O}(0.5 \mathrm{~g} / \mathrm{L})\right]$ with $\mathrm{pH} 4.0$ was mixed with substrate in $1: 2$ ratio (w/v) and autoclaved at $15 \mathrm{lb} / \mathrm{inch}^{2}$ pressure and $121{ }^{\circ} \mathrm{C}$ temperature for $20 \mathrm{~min}$. Then it was cooled and inoculated with $10 \%$ (w/v) spore suspension of $A$. awamori Nakazawa. Polygalacturonase production was carried out at $30{ }^{\circ} \mathrm{C}$ for $72 \mathrm{~h}$.

\section{$\alpha$-Amylase production}

Production of $\alpha$-amylase was carried out in a newly configured bioreactor (NB) according to the process de- scribed by Dey Banerjee (2012). Fermentation was carried out at $32{ }^{\circ} \mathrm{C}$ and $\mathrm{pH} 6.0$ for $48 \mathrm{~h}$.

\section{Extraction of enzyme from fermented mass}

In case of $\alpha$-amylase, enzyme was extracted according to the method described by Dey Banerjee (2012). In case of polygalacturonase, after fermentation, $20 \mathrm{~mL}$ water was mixed with the fermented biomass obtained after the fermentation of $5 \mathrm{~g}$ of ground apple pomace or mosambi peels and then it was soaked for $1 \mathrm{~h}$ in agitation mode. The mixture was centrifuged at 10,000 rpm and the supernatant was assayed for polygalacturonase activity.

\section{Decolourization and purification of crude enzyme with activated charcoal}

Decolourization and purification of enzymes were done according to the method of Aikat et al. (2001). Experiments were conducted in $1.5 \mathrm{~mL}$ micro-centrifuge tubes. Samples $(1 \mathrm{~mL})$ of crude enzyme from apple pomace $\left(C_{0}=1.984\right)$ and mosambi peel $\left(C_{0}=2.767\right)$ were treated with 20-120 mg of activated charcoal powder (purchased from Hi Media, India) and kept at room temperature $\left(30^{\circ} \mathrm{C}\right)$ for $15 \mathrm{~min}$. Crude $\alpha$-amylase $(1 \mathrm{~mL})$ from $A$. oryzae fermented wheat bran $\left(C_{0}=2.799\right)$ was treated with 20-320 mg of activated charcoal for $30 \mathrm{~min}$. The sample was centrifuged at $10,000 \mathrm{rpm}$ for $10 \mathrm{~min}$ and microfiltered. The filtrate was analyzed for colour intensity, enzyme activity and total protein content.

\section{Apple juice clarification}

\section{Raw apple juice preparation}

Unripe apples (Golden delicious) were picked two weeks before usual harvest date. Some of these apples were stored at room temperature for one week. Apples were cut to cubes and mashed in a mixer grinder and manually pressed using double layer cheesecloth to obtain raw or unclarified apple juice. In the extracted juice calcium chloride was added and the final concentration of this salt was $10 \mathrm{mM}$. Aliquots of this juice were pasteurized ( $5 \mathrm{~min}$ at $90 \pm 1{ }^{\circ} \mathrm{C}$ ) and immediately cooled to $50{ }^{\circ} \mathrm{C}$.

\section{Polygalacturonase concentration optimization}

In order to optimize the required concentration of polygalacturonase (apple pomace: $14.3 \mathrm{U} / \mathrm{mL}$ and mosambi peel: $9.87 \mathrm{U} / \mathrm{mL}$ ), the concentrations of the decolourized enzyme were varied from $0.25-1.25 \%(\mathrm{v} / \mathrm{v})$ in apple juice. The juice and enzyme mixture was incubated at $50{ }^{\circ} \mathrm{C}$ for $1 \mathrm{~h}$ to $3 \mathrm{~h}$ and $\%$ Transmittance at $660 \mathrm{~nm}$ was determined spectrophotometrically in order to check the clarity of the juice. The process was carried out in presence and in absence of $10 \mathrm{mM} \mathrm{CaCl}_{2}$ simultaneously. In the control set there was no enzyme. 


\section{$\alpha$-Amylase concentration optimization}

$\mathrm{CaCl}_{2}$ treated and untreated unclarified apple juice was mixed with decolourized polygalacturonase from mosambi peels $(9.87 \mathrm{U} / \mathrm{mL})$ at $1 \%(\mathrm{v} / \mathrm{v})$ concentration. Then decolourized $\alpha$-amylase $(899 \mathrm{U} / \mathrm{mL})$ was added at various concentrations $(0.1-1.25 \% ; \mathrm{v} / \mathrm{v})$. The mixture was incubated at $50{ }^{\circ} \mathrm{C}$ for $2 \mathrm{~h}$.

\section{Evaluation of different properties of clarified juice}

Decolourized polygalacturonase from mosambi peel $(1 \%)(\mathrm{v} / \mathrm{v})$ and $\alpha$-amylase $(0.4 \%)(\mathrm{v} / \mathrm{v})$ were added in the unclarified juice and incubated at $50{ }^{\circ} \mathrm{C}$ for $2 \mathrm{~h}$. The reaction was stopped by increasing the temperature of the mixture to $90{ }^{\circ} \mathrm{C}$ for $1 \mathrm{~min}$. Then it was centrifuged at $10,000 \mathrm{rpm}$ for $10 \mathrm{~min}$. The supernatant was analyzed for clarity $\left(\% \mathrm{~T}_{660 \mathrm{~nm}}\right)$, colour (absorbance at $440 \mathrm{~nm}$ ) and viscosity reduction ( $\%$ ) etc. Turbidity was determined using a portable turbidity meter and results were reported as Nephelometric Turbidity Units (NTU). Viscosity was measured using Oswald viscometer.

\section{Analytical methods}

\section{Polygalacturonase assay}

The reaction mixture $(1 \mathrm{~mL})$ containing equal amounts of polygalactouronic acid as substrate (1\%) prepared in acetate buffer ( $\mathrm{pH} 4.5)$ and suitably diluted enzyme was incubated in water bath at $50^{\circ} \mathrm{C}$ for $10 \mathrm{~min}$. After incubation, $3 \mathrm{~mL}$ DNS solution was added to stop the reaction and tubes were kept in boiling water for 15 min. After that $1 \mathrm{~mL}$ of $40 \%$ Rochelle's salt solution was added and cooled. After cooling, absorbance was read spectrophotometrically at $575 \mathrm{~nm}$ according to Miller method (Miller, 1959). One unit (U) of Polygalacturonase activity was calculated as the amount of enzyme required to release one $\mu \mathrm{mol}$ equivalent of galacturonic acid per min under assay condition and it was expressed in $\mathrm{U} / \mathrm{mL}$.

\section{$\alpha$-Amylase assay}

$\alpha$-Amylase activity was estimated according to the method described by Bhanja et al. (2007). One unit (U) of $\alpha$-amylase activity is defined as the amount of enzyme that liberates one $\mu \mathrm{mol}$ of reducing sugar (glucose) per min under the assay conditions. Results were expressed in $\mathrm{U} / \mathrm{mL}$.

\section{Starch detection and quantification}

Starch content was analyzed using iodine-starch reaction following the method of Carrin et al. (2004). Iodine solution $(126.9 \mathrm{mg} / \mathrm{L})$ was prepared by mixing same volume of $0.1 \mathrm{M}$ iodine and 5\% potassium iodide. An aliquot of $5 \mathrm{~mL}$ appropriately diluted sample was mixed with $2.5 \mathrm{~mL}$ of cold iodine solution and after $10 \mathrm{~min}$ at $25^{\circ} \mathrm{C}$ the absorbance was read at $615 \mathrm{~nm}$ with the Spectrophotometer. Results were compared with a calibration curve made with corn starch solutions of different concentrations.

\section{Determination of Total Phenolic Content (TPC)}

Total phenolic content was estimated according to Emmons and Peterson (2001). The amount of total phenolic content was calculated as gallic acid equivalent from the standard calibration curve of gallic acid and expressed as mg gallic acid equivalent.

\section{DPPH (2, 2-diphenyl-1-picrylhydrazyl) Radical Scavenging Assay}

The free radical scavenging activity of apple juice was measured by the $\mathrm{DPPH}^{\circ}$ scavenging method according to Brand-Williams et al. (1995). DPPH (Sigma-Aldrich Chemie, Steinheim, Germany) solution of $0.1 \mathrm{mM}$ concentration in methanol was added to $0.1 \mathrm{~mL}$ of phenolic extracts and $0.4 \mathrm{~mL}$ methanol. The change in absorbance at $515 \mathrm{~nm}$ was measured after $30 \mathrm{~min}$ of incubation. The DPPH radical-scavenging activity of phenolic extract from apple juice was calculated according to the following equation.

$$
\% \text { of PDDHscavenging activity }=\left[1-\left(\frac{\mathrm{Abs}}{\mathrm{Abc}}\right)\right] \times 100
$$

where, $\mathrm{AbC}$ was the absorbance of the control and $\mathrm{AbS}$ was the absorbance in the presence of the test compound.

\section{Results and Discussion}

\section{Decolourization of crude enzyme with activated charcoal}

During the decolourization process of polygalacturonase, $100 \mathrm{mg}$ charcoal was required per $\mathrm{mL}$ enzyme extract of both apple pomace (Figure 1A) and mosambi peel (Figure $1 \mathrm{~B}$ ) for the literature value of $10 \%$ remaining colour intensity (Gutcho, 1974). The corresponding polygalacturonase recoveries were nearly $65.1 \%$ and $69.8 \%$, respectively and fold purification were 8.6 and 34.8 , respectively.

In order to decolourize $\alpha$-amylase up to $90 \%, 125 \mathrm{mg}$ charcoal was required and the enzyme was 3.5-fold purified with $60 \%$ recovery (Figure $1 \mathrm{C}$ ). With less charcoal, a noticeable yellow colour sustained and the purification fold was lower. On the other hand, higher amount of charcoal resulted in considerable loss of enzyme. From these considerations and the literature value of $90 \%$ decolourization resulted in an almost colourless enzymes. Activated charcoal has many applications in the isolation and purification of biomolecules from crude fermentated broths (Aikat et al., 2001). It is a useful substance due to its large surface area, microporous nature, high adsorption capacity, high purity and easy availability. It also can be regenerated easily after use (Aikat and Bhattacharyya, 2001; Pradhan and Sandle, 1999).Using activated charcoal, protease was purified by Aikat et al. (2001) and Kumar (2003). Recently Murthy and Naidu (2011) utilized this charcoal for the purification of pectinase from Aspergillus niger CFR 305 however with only 4 folds purification. There is no such report available 

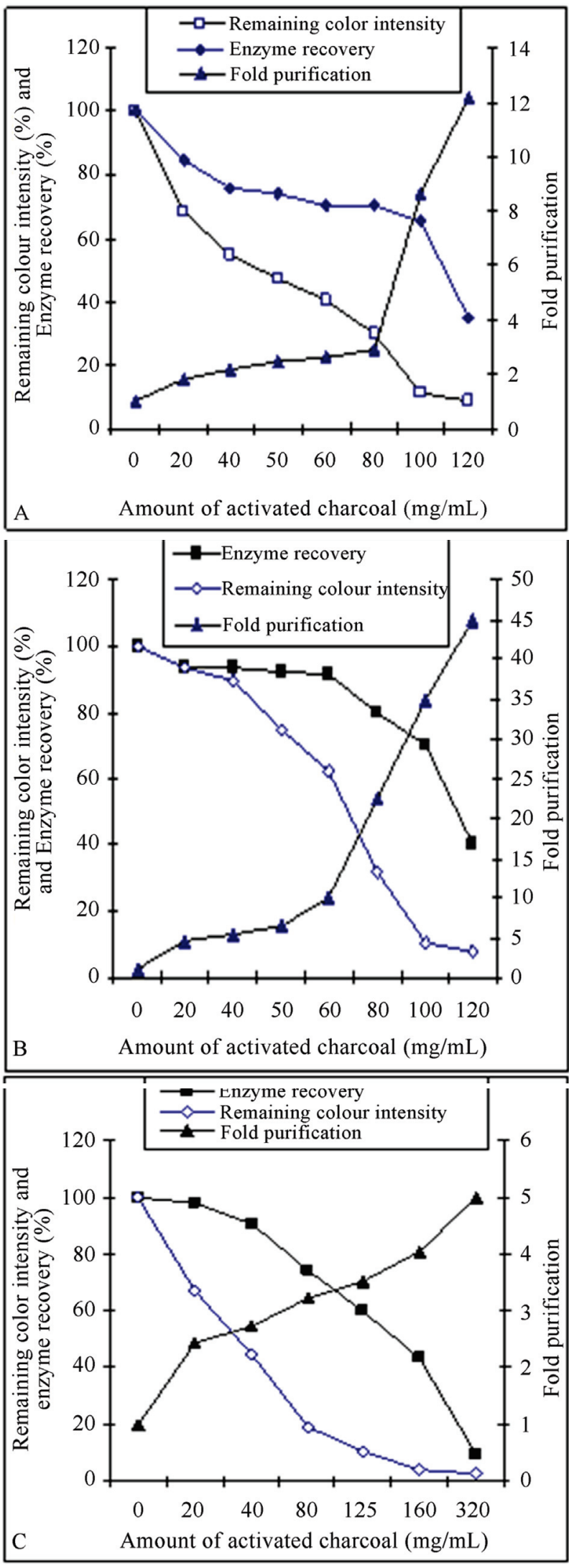

Figure 1 - Decolourization and partial purification of polygalacturonase from apple pomace (A), mosambi orange peels (B) and $\alpha$-amylase from wheat bran $(\mathrm{C})$. on $\alpha$-amylase and polygalacturonase purification by exploiting activated charcoal. In the present study, purification fold and enzyme recovery were significantly high in this single step purification process.

\section{Apple juice clarification by charcoal purified enzymes}

\section{Polygalacturonase treatment}

It was observed that in presence of $1 \%(\mathrm{v} / \mathrm{v})$ polygalacturonase from mosambi peel $(9.87 \mathrm{U} / \mathrm{mL})$, maximum clarity $\left(\% \mathrm{~T}_{660 \mathrm{~nm}}=96.4\right)$ of juice was attained after $2 \mathrm{~h}$ of incubation at $50{ }^{\circ} \mathrm{C}$. After $3 \mathrm{~h}$ of incubation, $\% \mathrm{~T}_{660 \mathrm{~nm}}$ remained constant. Although the polygalacturonase activity was lower in case of mosambi peel fermented product, it was most effective compared to polygalacturonase from apple pomace. Similarly, Nakkeeran et al. (2011) found that high activity polygalacturonase did not result in good juice clarity. Hence, $1 \%$ polygalacturonase from mosambi peel $(9.87 \mathrm{U} / \mathrm{mL})$ was taken as optimum concentration for apple juice clarification. Results are presented in Table 1. Upon enzymatic treatment, polygalacturonase broke down the pectin molecules of apple juice, which facilitated the formation of pectin-protein flocs leaving a clear supernatant and significantly removing the colloidal part of the juice (Yusof and Nurzarina, 1994; Alvarez et al., 1998). In general, enzyme concentration is the most important factor influencing the enzyme clarification. Increase in polygalacturonase concentration increased the $\% \mathrm{~T}_{660} \mathrm{~nm}$ or rate of clarification (Table 1) by exposing part of the positively charged protein beneath, thus reducing electrostatic repulsion between cloud particles which cause these particles to aggregate to larger particles and eventually settle out. Ishii and Yokotsuka (1972) found a slight stimulation by $0.7 \%$ $\mathrm{CaCl}_{2}$ in experiments on the clarification of Golden delicious apple juice by pectinlyase. Szajer and Szajer (1982) observed that enzymatic clarification of apple juice was stimulated by $\mathrm{Ca}^{2+}$ ions in a concentration of $10^{-2} \mathrm{M}$ by pectinlyase from Penicillium paxilii. Pectinlyase needs this ion as a cofactor. In the present study, there was no significant effect of $10 \mathrm{mM} \mathrm{CaCl}_{2}$ on polygalacturonase treatment.

\section{$\alpha$-Amylase treatment}

$\alpha$-Amylase, decolourized by $12.5 \%$ activated charcoal was utilized for apple juice clarification. Unclarified juice contained $1.143 \mathrm{~g} / \mathrm{L}$ starch. Figure 2 shows that in presence of $\mathrm{CaCl}_{2}$, with $40 \mu \mathrm{L} \alpha$-amylase i.e. $0.4 \% \alpha$-amylase concentration, starch content reduced to $0.33 \mathrm{~g} / \mathrm{L}$ then it remained constant. Therefore, $0.4 \% \alpha$-amylase was taken as optimum concentration for starch degradation. On the other hand, starch was not degraded in absence of $\mathrm{CaCl}_{2}$ as $\mathrm{pH}$ of the apple juice was 3.4 and incubated at $50{ }^{\circ} \mathrm{C}$ for $2 \mathrm{~h}$. In such a condition $\alpha$-amylase activity of $A$. oryzae should be very less (Sahnoun et al., 2012). Some amount of 
Table 1 - Effects of incubation period and polygalacturonase concentration on apple juice clarification

\begin{tabular}{|c|c|c|c|c|c|c|c|}
\hline \multirow[t]{3}{*}{ Type of enzyme } & \multirow{3}{*}{$\begin{array}{l}\text { Enzyme con- } \\
\text { centration }(\%)\end{array}$} & \multicolumn{6}{|c|}{$\%$ Transmittance at $660 \mathrm{~nm}$} \\
\hline & & \multicolumn{2}{|c|}{$1 \mathrm{~h}$} & \multicolumn{2}{|c|}{$2 \mathrm{~h}$} & \multicolumn{2}{|c|}{$3 \mathrm{~h}$} \\
\hline & & $\begin{array}{l}\text { With } 10 \mathrm{mM} \\
\mathrm{CaCl}_{2}\end{array}$ & $\begin{array}{l}\text { Without } 10 \mathrm{mM} \\
\mathrm{CaCl}_{2}\end{array}$ & $\begin{array}{c}\text { With } 10 \mathrm{mM} \\
\mathrm{CaCl}_{2}\end{array}$ & $\begin{array}{l}\text { Without } 0 \mathrm{mM} \\
\mathrm{CaCl}_{2}\end{array}$ & $\begin{array}{c}\text { With } 10 \mathrm{mM} \\
\mathrm{CaCl}_{2}\end{array}$ & $\begin{array}{c}\text { Without } 10 \mathrm{mM} \\
\mathrm{CaCl}_{2}\end{array}$ \\
\hline \multirow{6}{*}{$\begin{array}{l}\text { Polygala-cturonase } \\
\text { from apple pomace } \\
(14.3 \mathrm{U} / \mathrm{mL})\end{array}$} & 0 & $42.6 \pm 0.5$ & $44.0 \pm 0.7$ & $43.0 \pm 0.9$ & $44.5 \pm 0.8$ & $44.0 \pm 0.5$ & $44.5 \pm 0.6$ \\
\hline & 0.25 & $47.2 \pm 0.6$ & $48.9 \pm 0.8$ & $83.3 \pm 0.7$ & $83.4 \pm 0.4$ & $84.1 \pm 0.7$ & $84.5 \pm 0.7$ \\
\hline & 0.50 & $50.9 \pm 0.3$ & $50.5 \pm 0.3$ & $86.7 \pm 0.6$ & $87.6 \pm 0.5$ & $87.9 \pm 0.6$ & $88.0 \pm 0.6$ \\
\hline & 0.75 & $52.0 \pm 0.5$ & $52.1 \pm 0.5$ & $86.8 \pm 0.7$ & $87.8 \pm 0.5$ & $89.9 \pm 0.4$ & $90.1 \pm 0.4$ \\
\hline & 1.00 & $52.3 \pm 0.5$ & $53.7 \pm 0.8$ & $89.3 \pm 0.8$ & $88.7 \pm 0.4$ & $90.3 \pm 0.4$ & $91.0 \pm 0.8$ \\
\hline & 1.25 & $52.4 \pm 0.6$ & $53.7 \pm 0.9$ & $89.6 \pm 0.6$ & $88.9 \pm 0.9$ & $91.0 \pm 0.3$ & $91.8 \pm 0.5$ \\
\hline \multirow{6}{*}{$\begin{array}{l}\text { Polygala-cturonase } \\
\text { from mosambi peel } \\
(9.87 \mathrm{U} / \mathrm{mL})\end{array}$} & 0 & $44.5 \pm 0.6$ & $44.0 \pm 0.7$ & $43.0 \pm 0.7$ & $44.5 \pm 0.9$ & $44.5 \pm 0.9$ & $44.5 \pm 0.6$ \\
\hline & 0.25 & $84.5 \pm 0.7$ & $47.4 \pm 0.7$ & $86.7 \pm 0.9$ & $87.9 \pm 0.5$ & $87.9 \pm 0.5$ & $86.1 \pm 0.4$ \\
\hline & 0.50 & $88.0 \pm 0.6$ & $54.1 \pm 0.5$ & $91.5 \pm 0.8$ & $91.1 \pm 0.4$ & $91.1 \pm 0.4$ & $93.1 \pm 0.3$ \\
\hline & 0.75 & $90.1 \pm 0.4$ & $58.4 \pm 0.8$ & $92.6 \pm 0.8$ & $92.8 \pm 0.5$ & $92.8 \pm 0.5$ & $94.4 \pm 0.7$ \\
\hline & 1.00 & $91.0 \pm 0.8$ & $69.1 \pm 0.9$ & $96.4 \pm 0.4$ & $95.0 \pm 0.3$ & $95.0 \pm 0.3$ & $95.0 \pm 0.2$ \\
\hline & 1.25 & $91.8 \pm 0.5$ & $70.2 \pm 0.4$ & $96.7 \pm 0.5$ & $95.6 \pm 0.5$ & $95.6 \pm 0.5$ & $95.5 \pm 0.5$ \\
\hline
\end{tabular}

Data are represented by the mean \pm SD of three replications.

$\mathrm{Ca}^{2+}$ might be present in the juice, yet that amount might not have been sufficient. Therefore, $\mathrm{CaCl}_{2}$ in $10 \mathrm{mM}$ concentration was used in the present investigation.

\section{Different properties of clarified apple juice}

The juice yield in percent $(\mathrm{mL} / 100 \mathrm{~g}$ of fresh apple slice) was calculated taking $142 \mathrm{~g}$ of apple slice. From $142 \mathrm{~g}$ of apple slice, the volume of extracted raw juice (Figure $3 \mathrm{U}$ ) was $110 \mathrm{~mL}$ and after clarification (Figure 3C) extracted volume increased to $112 \mathrm{~mL}$. The yield of unclarified juice was $77 \%$, but increased to $79 \%$ after clarification. Commercial sources of fungal pectic enzymes have been used in fruit juice processing since 1930's for clarifying fruit juices and disintegrating plant pulps to increase

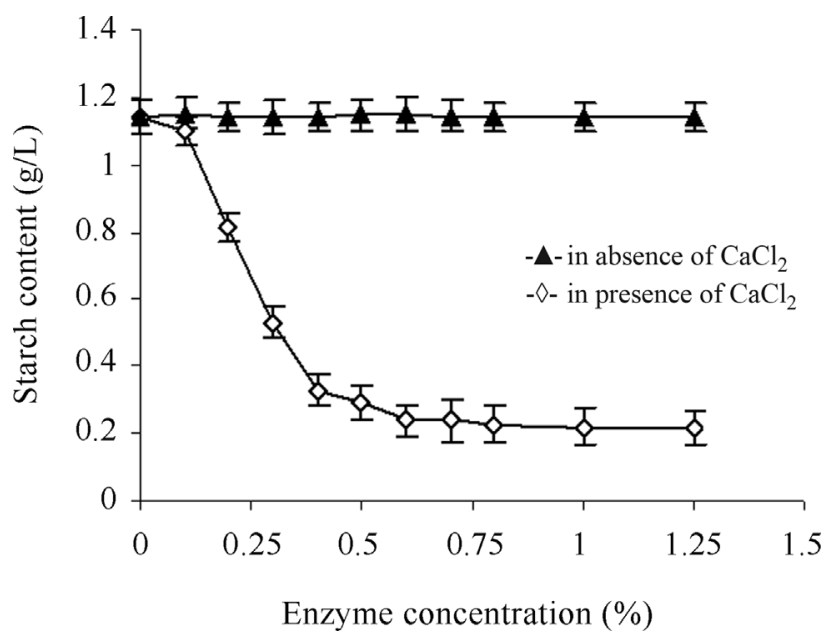

Figure 2 - Degradation of apple starch with different concentrations of $\alpha$-amylase. juice yields. In the present study, although the yield increased only $2 \%$, it will be cost-effective for large-scale juice production.

Table 2 shows that after clarification, the $\% \mathrm{~T}_{660 \mathrm{~nm}}$ of juice was $97 \%$, without gelatin/bentonite treatment and ultrafiltration. It was also observed that there was no difference of $\% \mathrm{~T}_{660} \mathrm{~nm}$ value of $10 \mathrm{mM} \mathrm{CaCl}$ treated and untreated unclarified juice. Hence, without enzymatic treatment, $\mathrm{CaCl}_{2}$ was not participating in depectinization of apple juice.

After enzyme treatment, the colour intensity of the juice reduced $\left(\mathrm{A}_{440 \mathrm{~nm}}=0.280\right)$ and the viscosity came down by $40 \%$. The turbidity decreased from 31.6 to $3.9 \mathrm{NTU}$ in clarified juice and after two months of storage at $4{ }^{\circ} \mathrm{C}$ it was 4.1 NTU. There was no difference in turbidity values be-

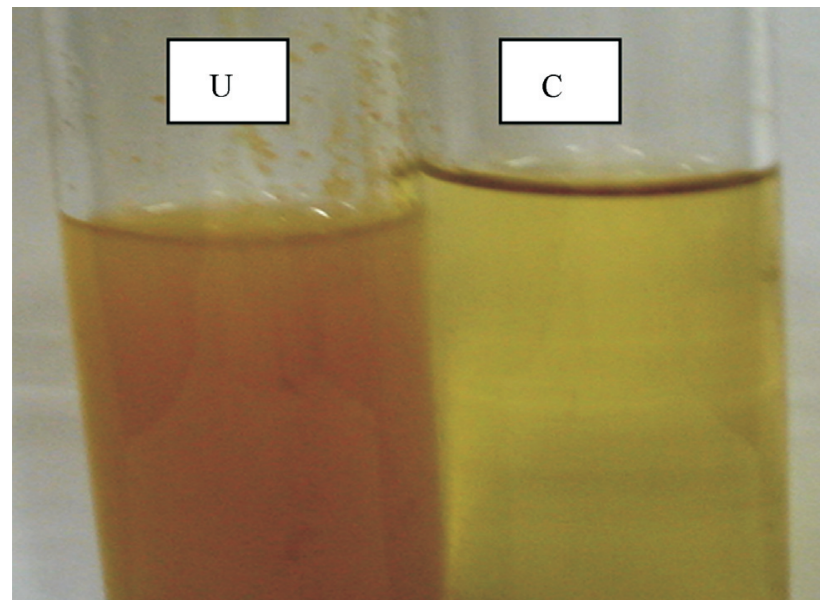

Figure 3 - Unclarified (U) and clarified juice (C). 
Table 2 - Properties of unclarified and clarified apple juice.

\begin{tabular}{|c|c|c|c|}
\hline Properties & $\begin{array}{l}\text { Unclarified juice without } \\
\qquad 10 \mathrm{mM} \mathrm{CaCl}_{2}\end{array}$ & $\begin{array}{l}\text { Unclarified juice with } \\
\qquad 10 \mathrm{mM} \mathrm{CaCl}_{2}\end{array}$ & $\begin{array}{l}\text { Clarified juice with } \\
10 \mathrm{mM} \mathrm{CaCl}_{2}\end{array}$ \\
\hline Juice recovery $(\%)(\mathrm{v} / \mathrm{w})$ & $77 \%$ & $77 \%$ & $79 \%$ \\
\hline$\% \mathrm{~T}_{660 \mathrm{~nm}}$ & $44.5 \%$ & $43.0 \%$ & $97.0 \%$ \\
\hline Absorbance at $440 \mathrm{~nm}$ & 1.427 & 1.489 & 0.280 \\
\hline Viscosity reduction & $0 \%$ & $0 \%$ & $40 \%$ \\
\hline $\mathrm{pH}$ & 3.4 & 3.4 & 3.2 \\
\hline Turbidity (NTU) & 31.6 & 33.9 & 3.9 \\
\hline Reducing sugar & $102.6 \mathrm{mg} / \mathrm{mL}$ & $103.0 \mathrm{mg} / \mathrm{mL}$ & $110.8 \mathrm{mg} / \mathrm{mL}$ \\
\hline TPC (mg gallic acid equivalent) & $1.26 \mathrm{mg} / \mathrm{mL}$ & $1.25 \mathrm{mg} / \mathrm{mL}$ & $1.01 \mathrm{mg} / \mathrm{mL}$ \\
\hline$\%$ DPPH• scavenging activity & $77.0 \%$ & $77.5 \%$ & $81.0 \%$ \\
\hline
\end{tabular}

tween $10 \mathrm{mM} \mathrm{CaCl}$ treated and untreated unclarified juices. Total reducing sugar content increased after clarification of juice (Table 2).

Clarity $\left(\% \mathrm{~T}_{650}\right)$ is an important index of clarified juice. The most effective clarification $\left(\% \mathrm{~T}_{650}, 85 \%\right.$; $\mathrm{p}<.001)$ was achieved by Singh and Gupta (2004), with $15 \mathrm{IU} / \mathrm{mL}$ of pectinolytic enzyme preparation from $A$. niger van Tieghem, in presence of $0.01 \%$ gelatine, at $45^{\circ} \mathrm{C}$ in $6 \mathrm{~h}$ holding time. Immobilized pectolytic enzyme (24 U) at $45^{\circ} \mathrm{C}$ and $1 \mathrm{~h}$ incubation time increased the transmittance of apple juice by about $55 \%$ at $650 \mathrm{~nm}$ (Saxena et al., 2008). However, in the present study, it was found that only in presence of $1 \%(\mathrm{v} / \mathrm{v})$ decolourized polygalacturonase from mosambi peel $(9.87 \mathrm{U} / \mathrm{mL})$ and $0.4 \%(\mathrm{v} / \mathrm{v})$ decolourized $\alpha$-amylase $\left(899 \mathrm{U} / \mathrm{mL}\right.$ ) the $\% \mathrm{~T}_{660 \mathrm{~nm}}$ of clarified juice was $97 \%$. Such a high clarity is rare without ultrafiltration and fining agent like gelatin/bentonite.

Colour is an important sensory attribute. A dark product is usually less pleasing to the consumers as it may indicate deterioration. As absorbance at $440 \mathrm{~nm}$ was very low for clarified juice, it should be more appealing. The value supported the result of Diano et al. (Diano et al., 2008), where immobilized pectolytic enzymes were used for apple juice clarification.

Turbidity in fruit juices can be a positive or negative attribute, depending on the expectation of the consumers (Hutchings, 1999). In the case of orange and tomato juices, the juices are usually cloudy and have colloidal suspensions. However, this cloud is desirable and acceptable by the consumers. For clarified fruit juices, a juice that has an unstable cloud or whose turbidity is considered "muddy" is unacceptable to be marketed as clear juices (Floribeth et al., 1981). After the clarification of juice, the amount of pectin in the juice decreased, while galacturonic acid monomers and oligomers remained in the juice. The galacturonic compounds did not contribute to juice turbidity. Moreover, after two months of storage at $4{ }^{\circ} \mathrm{C}$, the turbidity was not increased too much.

It was also found that there was no difference of $\% \mathrm{~T}_{660 \mathrm{~nm}}$ and turbidity values between unclarified juice treated with and without $10 \mathrm{mM} \mathrm{CaCl} 2$. Hence it could be concluded that only $\mathrm{Ca}^{2+}$ was not involved in the sedimentation process, moreover enzymes in presence of $10 \mathrm{mM}$ $\mathrm{CaCl}_{2}$ was clarifying the juice.

It is shown that fruit juices with high viscosity may lead to problems during the filtration process (Alvarez et al., 1998; Kashyap et al., 2001; Vaillant et al., 2001). Soluble pectinacious materials, hemicellulose, soluble polysaccharides and colloids are responsible for high viscosity. Enzymes degrade these materials by hydrolysis leading to easy filtration of the juice. Viscosity reduction of fruit juice by enzymatic hydrolysis of pectin was reported by Urlaub (1996). Similarly, during enzymatic treatment of apple juice, viscosity reduction of $\sim 4.5 \%, \sim 36 \%$, and $\sim 35 \%$ were reported by Yuan et al. (2011), Singh and Gupta (2004) and Busto et al. (2006) respectively, while in the present study, $40 \%$ reduction was observed. On the contrary reduction in viscosity of juice by $\sim 66 \%$ and $82-91 \%$ were observed by Nakkeeran et al. (2011) and Oszmianski et al. (2009) respectively. There might be many factors like type of enzyme preparation, apple variety, treatment and pressing conditions, which were responsible for such variation of viscosity reduction.

Starch was also responsible for the slow filtration or high viscosity of juice. In the present study, $\alpha$-amylase synergistically acted with polygalacturonase for the reduction of viscosity.

Total reducing sugar content was increased in clarified apple juice after polygalacturonase and $\alpha$-amylase treatment. This is because the enzymes released galacturonic acid, glucose, dextrin, maltose and other reducing sugars from pectin and starch during hydrolysis.

TPC of juice was reduced by $19.8 \%$ after clarification (Unclarified: $1.26 \mathrm{mg}$ gallic acid equivalent/mL; Clarified: $1.05 \mathrm{mg}$ gallic acid equivalent $/ \mathrm{mL}$ ) might be due to the fact that very small amount of charcoal might be present in the decolourized enzymes although they were centrifuged properly and filtered through $0.33 \mu \mathrm{m}$ filter membrane. Phenolics, which are responsible for haze formation and browning during storage of clear apple juice and concen- 
trates, should be selectively removed. A number of agents including gelatine, bentonite, activated charcoal, casein, ion-exchange waxes and polyvinylpolypyrrolidone (PVPP) have been studied for the removal of phenolics from fruit juices. However, these are all used in batch processes, which lead to additional costs in the existing processing line (Borneman et al., 2001, Youn et al., 2004; Benitez and Lozano, 2007). In the present study, the decolourized and partially purified enzymes improved the clarity of the juice as well as reduced the amount of some of the haze active phenolics.

Interestingly, a higher \%DPPH radical scavenging property was noted (Unclrarified: $77 \%$; Clarified: $81 \%$ ). Phenolics occur primarily in conjugated form in unclarified juice with one or more sugar residues binding to the hydroxyl group. This condition lowered the antioxidant activity in unclarified juice, since availability of free hydroxyl group on the phenolic structure is an important characteristic for the resonance stabilization of free radicals. Carbohydratases like polygalacturonase and $\alpha$-amylase, exposed the hydroxyl group. That might be the reason for enhanced antioxidant property in clarified juice though lesser amount of phenolic compounds was present in it. Hence, it is established that the enzymatic hydrolysis improves the nutraceutical potential of apple juice by releasing the free aglycones. Again, it is proved that not only the phenolic content, but also phenolic composition or structure plays a major role for antioxidant activity (Bhanja et al., 2008).

\section{Conclusions}

$\alpha$-Amylase and polygalacturonase were successfully decolourized and purified by activated charcoal with significantly high purification fold and recovery. Hence, activated charcoal having efficient adsorption power can be utilized for cost-effective downstream processing of these enzymes. The method can be easily applied in large scale purification process for commercial use. Decolourized $\alpha$-amylase and polygalacturonase were utilized for the clarification of apple juice fruitfully. The influence of calcium ions was remarkable as enzymatic clarification of the juice was stimulated by $\mathrm{Ca}^{2+}$ ions. The clarification process was very simple, easy and cost-effective and the clarified juice was stable above two months. The clarified juice had less phenolic content, however, with higher DPPH radical scavenging property. It can be concluded that the calcium fortified antioxidant rich apple juice would be a good health drink.

\section{Acknowledgement}

The authors are thankful to Late Prof. B.C. Bhattacharyya for providing the novel NB system designed by him. The authors gratefully acknowledge the Department of Biotechnology, Govt. of India, New Delhi for financial assistance.

\section{References}

Aikat K, Bhattacharyya BC (2001) Regeneration of activated charcoal used in decolorization and purification of crude protease from Rhizopus oryzae. Biotechnol Lett 23:19151919.

Aikat K, Maiti TK, Bhattacharyya BC (2001) Decolorization and purification of crude protease from Rhizopus oryzae by activated charcoal and its electrophoretic analysis. Biotechnol Lett 23: 295-301.

Alvarez S, Alvarez R, Riera FA, Coca J (1998) Influence of depectinization on apple juice ultrafiltration. Colloids Surf A 138:377-382.

Benitez EI, Lozano, JE (2007) Effect of gelatin on apple juice turbidity. Lat Am Appl Res 37:261-266.

Bhanja T, Rout S, Banerjee R, Bhattacharyya BC (2008) Studies on the performance of a new bioreactor for improving antioxidant potential of rice. LWT-Food Sci Technol 41:14591465.

Bhanja T, Rout S, BanerjeeR, Bhattacharyya BC (2007) Comparative profiles of $\alpha$-amylase production in conventional tray reactor and GROWTEK bioreactor. Bioproc Biosys Eng 30:369-376.

Borneman Z, Gokmen V, Nijhuis HH (2001) Selective removal of polyphenols and brown colour in apple juices using PES/PVP membranes in a single ultrafiltration process. Sep Purif Technol 22-23:53-61.

Brand-Williams W, Cuvelier ME, Berset C (1995) Use of a free radical method to evaluate antioxidant activity. LWT-Food Sci Technol 28:25-30.

Busto MD, Garcia-Tramontin KE, Ortega N, Perez-Mateos M (2006) Preparation and properties of an immobilized pectinlyase for the treatment of fruit juices. Bioresour Technol 97:1477-1483.

Carrin ME, Ceci LN, Lozano JE (2004) Characterization of starch in apple juice and its degradation by amylases. Food Chem 87:173-178.

Ceci LN, Lozano JE (1998) Determination of enzymatic activities of commercial pectinases for the clarification of apple juice. Food Chem 61:237-241.

Ceci LN, Lozano JE (2002) Amylase for apple juice processing: Effects of $\mathrm{pH}$, heat, and $\mathrm{Ca}^{2+}$ ions. Food Technol Biotechnol 40:33-38.

Dey TB, Banerjee R (2012) Hyper active $\alpha$-amylase production by Aspergillus oryzae IFO 30103 by solid state fermentation. Lett Appl Microbio 54:102-107.

Diano N, Grimaldi T, Bianco M, Rossi S, Gabrovska K, Yordanova G, et al. (2008). Apple juice clarification by immobilized pectolytic enzymes in packed or fluidized bed reactors. J Agri Food Chem 56:11471-11477.

Emmons CL, Peterson DM (2001) Antioxidant activity and phenolic content of Oat as affected by cultivar and location. Crop Sci 41:1676-1681.

Floribeth V, Celsa L, Cooke RD (1981) A study of the production of clarified banana juice using pectinolytic enzymes. Food Technol 16:115-125.

Grampp E (1977) Hot clarification process improves production of apple juice concentrate. Food Technol 31:38-43.

Gutcho SJ (1974) Microbial Enzyme Production. pp. 230-237. Noyes Data Corporation, USA. 
Hutchings JB (1999) Food colour and appearance. $2^{\text {nd }}$ ed. An Aspen Publication, USA.

Ishii S, Yokotsuka T (1972) Purification and properties of pectin trans-eliminase from Aspergillus sojae. Agr Biol Chem 36:146-153.

Kahle K, Kraus M, Richling E (2005) Polyphenol profiles of apple juices. Mol Nutr Food Res 49:797-806.

Kashyap DR, Vohra PK, Chopra S, Tewari R (2001) Applications of pectinases in the commercial sector: A review. Bioresour Technol 77: 215-27.

Kumar CGP (2003) Activated charcoal: a versatile decolorization agent for the recovery and purification of alkaline protease. World J Microbiol Biotechnol 19:243-246.

Miller GL (1959) Use of dinitrosalicylic acid reagent for determination of reducing sugar. Anal Chem 31:426-429.

Murthy PS, Naidu MM (2011) Improvement of Robusta Coffee Fermentation with Microbial Enzymes. Eur J Appl Sci 3:130-139.

Nakkeeran E, Kumar SU, Subramanian R (2011) Aspergillus carbonarius polygalacturonases purified by integrated membrane process and affinity precipitation for apple juice production. Bioresour Technol 102:3293-3297.

Oszmianski J, Wojdylo A, Kolniak J (2009) Effect of enzymatic mash treatment and storage on phenolic composition, antioxidant activity, and turbidity of cloudy apple juice. J Agri Food Chem 57:7078-7085.

Pradhan BK, Sandle NK (1999) Effect of different oxidizing agent treatments on the surface properties of activated carbons. Carbon 37:323-332.

Sahnoun M, Bejar S, Sayari A, Triki MA, Kriaa M, Kammoun R (2012) Production, purification and characterization of two $\alpha$-amylase isoforms from a newly isolated Aspergillus oryzae strain S2. Process Biochem 47:18-25.

Saxena S, Shukla S, Thakur A, Gupta R (2008) Immobilization of polygalacturonase from Aspergillus niger onto activated polyethylene and its application in apple juice clarification. Acta Microbiologica et Immunologica Hungarica 55:33-51.

Singh S, Gupta R (2004) Apple juice clarification using fungal pectinolytic enzyme and gelatine. Indian J Biotechnol 3:573-576.

Szajer I, Szajer C (1982) Clarification of apple juices by pectin lyase from Penicillium paxilli. Biotechnol Lett 4:553-556.

Urlaub R (1996) Advantages of enzymatic apple mash treatment and pomace liquefaction. Fruit Processing 6:399-406.

Vaillant F, Millan A, Dornier M, Decloux M, Reynes M (2001) Strategy for economical optimization of the clarification of pulpy fruit juices using crossflow microfiltration. Food Eng 48:83-90.

Youn KS, Hong JH, Bae DH, Kim SJ, Kim SD (2004) Effective clarifying process of reconstituted apple juice using membrane filtration with filter-aid pretreatment. J Membr Sci 228:179-186.

Yuan P, Meng K, Huang H, Shi P, Luo H, Yang P, Yao B (2011) A novel acidic and low-temperature-active endo-polygalacturonase from Penicillium sp. CGMCC 1669 with potential for application in apple juice clarification. Food Chem 129:1369-1375.

Yusof S, Nurzarina I (1994) Quality of soursop juice after pectinase enzyme treatment. Food Chem 51:83-88.

All the content of the journal, except where otherwise noted, is licensed under a Creative Commons License CC BY-NC. 